\title{
LETTERS
}

\section{Epstein-Barr virus acute acalculous cholecystitis}

I thank the authors of the article titled "Epstein-Barr virus infection associated with acute acalculous cholecystitis in a 20-year-old woman" for highlighting an interesting variation on the standard narrative of acalculous cholecystitis. ${ }^{1}$ The thought-provoking angle was not the computed tomography (CT) imaging, but rather the description of a "benign" form of acalculous cholecystitis associated with Epstein-Barr virus infection. Given this, I would appreciate the authors' elaboration on certain clinical aspects regarding the case.

First, this patient has a noticeable derangement in liver enzymes. I wondered whether the patient was jaundiced.

Second, the case report seems to suggest that the acalculous status of the patient was diagnosed on CT findings alone. Computed tomography is helpful in diagnosing the complications of acute cholecystitis. ${ }^{2}$ However, CT scan has a low sensitivity for detecting gallstones (39\%-75\%), which are usually radiolucent. ${ }^{3}$ Ultrasound has a $95 \%$ sensitivity and specificity for detecting cholecystolithiasis. ${ }^{3}$ Could the authors comment on this?

My last question relates to the management of acalculous cholecystitis which, in general, is known to have a high mortality rate. Acalculous cholecystitis has a multifactorial pathogenesis associated with substantial inflammation and necrosis of the gallbladder wall. The ultimate cause of death is sepsis and multiorgan failure from secondary infection with enteric pathogens and a high perforation rate. ${ }^{4}$ Wang and colleagues found, among other factors, a high leukocyte count (mean of $15.89 \times 10^{9} / \mathrm{L}$ ) to be one of the important indicators of severe gallbladder complications and subsequent death. ${ }^{4}$
The authors of this case report stated, "Most cases [of acalculous cholecystitis associated with Epstein-Barr virus] resolve spontaneously without antibiotics or surgical intervention" and imply that the diagnosis of acalculous cholecystitis associated with Epstein-Barr virus was made based on the clinical picture and imaging findings. How long did it take to obtain confirmatory antibody testing for the virus? In the interim, while waiting for test results, was this patient with acalculous cholecystitis and a leukocytosis of $17.0 \times 10^{9} / \mathrm{L}$ on antibiotics?

\section{Jacobus S. Vermaak MBBCh MMed(Surg)}

General surgeon, Sir Thomas Roddick

Hospital, Stephenville, NL

- Cite as: CMAJ 2021 July 26;193:E1143. doi: $10.1503 / \mathrm{cmaj} .79128$

\section{References}

1. Nakagawa H, Miyata Y. Epstein-Barr virus infection associated with acute acalculous cholecystitis in a 20-year-old woman. CMAJ 2021;193:E696

2. Yeh DD, Cropano C, Fagenholz P, et al. Gangrenous cholecystitis: deceiving ultrasounds, significant delay in surgical consult, and increased postoperative morbidity! J Trauma Acute Care Surg 2015; 79:812-6.

3. Benarroch-Gampel J, Boyd CA, Sheffield KM, et al. Overuse of computed tomography in patients with complicated gallstone disease. J Am Coll Surg 2011;213:524-30.

4. Wang AJ, Wang TE, Lin CC, et al. Clinical predictors of severe gallbladder complications in acute acalculous cholecystitis. World J Gastroenterol 2003;9:2821-3.

Competing interests: None declared.

Content licence: This is an Open Access article distributed in accordance with the terms of the Creative Commons Attribution (CC BY-NC-ND 4.0) licence, which permits use, distribution and reproduction in any medium, provided that the original publication is properly cited, the use is noncommercial (i.e., research or educational use), and no modifications or adaptations are made. See: https://creativecommons.org/ licenses/by-nc-nd/4.0/ 